\title{
PENGARUH MODEL PEMBELAJARAN TEAMS GAMES TOURNAMENT BERBANTUAN ALAT PERAGA TERHADAP KEMAMPUAN PEMAHAMAN KONSEP MATEMATIS SISWA
}

\author{
Ainun Rahmi ${ }^{1)}$, Nuraina ${ }^{2) *}$, Yeni Listiana ${ }^{3)}$ \\ 1,2,3 Program Studi Pendidikan Matematika, Universitas Malikussaleh, Aceh Utara \\ *Korespondensi Penulis. E-mail: nuraina@unimal.ac.id
}

\begin{abstract}
Abstrak
Penelitian ini bertujuan untuk mengetahui pengaruh model pembelajaran Teams Games Tournament (TGT) berbantuan alat peraga terhadap kemampuan pemahaman konsep matematis siswa pada materi bangun runag sisi datar bagian kubus dan balok. Penelitian ini menggunakan pendekatan kuantitatif, jenis penelitian yang digunakan ialah quasi experimental design dengan rancangan penelitian the nonequivalent posttest-only control grup design. Populasi pada penelitian ini adalah seluruh siswa kelas VIII MTsN 2 Aceh Tenggara tahun ajaran 2020/2021. Sampel pada penlitian ini merupakan siswa kelas VIII-A dan siswa kelas VIII-B yang dipilih dengan teknik purposive sampling. Instrumen yang digunakan dalam penelitian ini adalah tes kemampuan pemahaman konsep matematis yang berupa post test. Data yang diperoleh dari penelitian dianalisis menggunakan softwere SPSS 18. Nilai ratarata post test pada kelas eksperimen dan kelas kontrol adalah 13,56 dan 11,32. Dari hasil uji-t diperoleh hasil Significan 2-tailed $<\alpha(0,009<0,05)$, sehingga $\mathrm{H}_{0}$ ditolak dan $\mathrm{H}_{1}$ diterima. Berdasarkan analisis tersebut menunjukan bahwa terdapat pengaruh yang signifikan model pembelajaran Teams Games Tournament (TGT) berbantuan alat peraga terhadap kemampuan pemahaman konsep matematis siswa pada materi bangun ruang sisi datar kelas VIII MTsN 2 Aceh Tenggara.
\end{abstract}

Kata Kunci: Teams Games Tournament (TGT), alat peraga, pemahaman konsep

\section{PENDAHULUAN}

Pembelajaran matematika memiliki tujuan yang ingin dicapai, seperti yang termuat dalam Kurikulum 2013 Lampiran 3 Permendikbud No. 58 (Kemendikbud, 2014) salah satu tujuan yang ingin dicapai dalam pembelajaran matematika pada kurikulum 2013 adalah kemampuan pemahaman konsep matematis siswa. Mills (Rahmat, Suwatno, \& Rasto, 2018) mengatakan bahwa kemampuan pemahaman konsep matematis siswa merupakan suatu landasan dalam membangun pengetahuan selanjutnya, penerapan pemahaman konseptual ini melampaui satu topik dalam kurikulum dan memiliki potensi untuk mempengaruhi banyak bidang pendidikan. Namun, hasil wawancara dan observasi peneliti pada saat Praktik Pengalaman Lapangan (PPL) pada tanggal 27 Oktober hingga 30 November 2020 dengan salah satu guru matematika di MTsN 2 Aceh Tenggara kelas VIII serta hasil tes kemampuan pemahaman konsep matematis siswa yang dilaksanakan peneliti sebagai observasi awal pada siswa kelas VIII MTsN 2 Aceh Tenggara dimana hasilnya bahwa banyak siswa yang kesulitan dalam memahami konsep matematika, seperti siswa tidak dapat mendefinisikan kembali konsep suatu materi pelajaran matematika dengan bahasa mereka sendiri, serta tidak dapat membedakan antara contoh dan bukan contoh dari sebuah konsep suatu materi tersebut, bahkan memaknai matematika dalam bentuk nyata. 


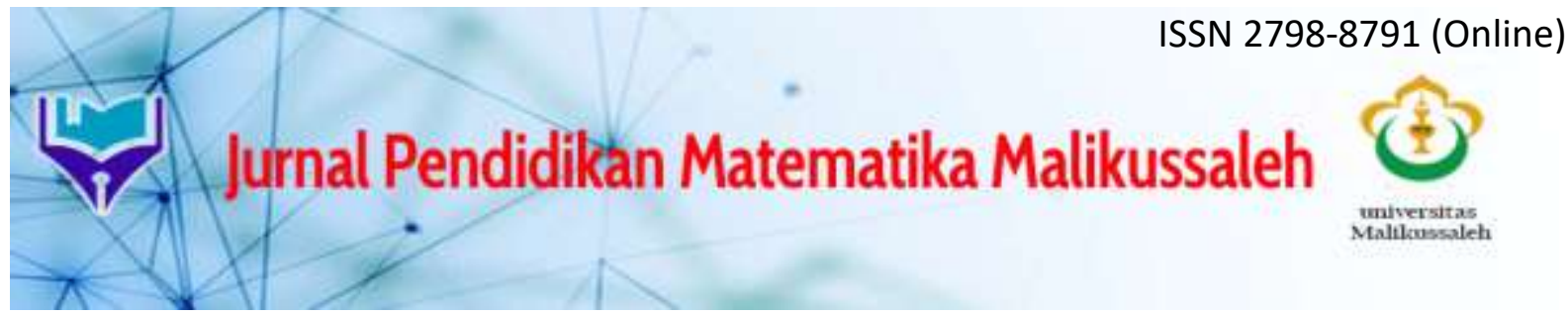

Volume 1, Nomor 2, November 2021

Salah satu upaya yang dapat dilakukan untuk memperbaiki permasalahan diatas ialah dengan menerapkan model pembelajaran. Model pembelajaran yang berorentasi pada hal tersebut ialah model pembelajaran kooperatif yaitu tipe Teams Games Tournament (TGT). Model pembelajaran TGT dapat menstimulus atau merangsang keterlibatan peserta didik terhadap materi pelajaran yang diberikan, sehingga siswa yang pasif menjadi aktif dalam belajar. Seperti penelitian yang telah dilakukan oleh Rohmah, dan Wahyudin hasil penelitian menunjukan bahwa pembelajaran kooperatif tipe TGT berbantuan media game online dapat meningkatkan kemampuan pemahaman konsep dan penalaran matematis siswa (Rohmah \& Wahyudi, 2016).

Selain penerapan model pembelajaran yang sesuai, alat peraga juga dapat membantu siswa menjadi lebih aktif dalam proses pembelajaran dan berakibat dapat meningkatkan kemamapuan pemahaman konsep matematis siswa pada materi tersebut. alat peraga yang akan digunakan peneliti dalam penelitian ialah alat peraga Alperbus (Alat peraga balok kubus). Alperbus merupakan alat peraga yang terbuat dari kertas karton yang dibuat menjadi bentuk kubus dan balok. Alat perga Alperbus ini berguna untuk menghitung jaring-jaring, menemukan konsep luas permukaan serta volume kubus dan balok.

Berdasarkan uraian di atas, permasalahan kemampuan pemahaman konsep matematis siswa yang rendah dapat diselesaikan dengan model pembelajaran TGT serta berbantuan alat peraga. Maka dari itu, peneliti melakukan penelitian di MTsN 2 Aceh Tenggara dengan judul "Pengaruh Model Pembelajaran Teams Games Tournament (TGT) Berbantuan Alat Peraga Terhadap Kemampuan Pemahaman Konsep Matematis Siswa Kelas VIII MTsN 2 Aceh Tenggara".

Sanjaya (Batubara, 2017) mengemukakan bahwa kemampuan pemahaman konsep matematis siswa adalah kemampuan siswa yang berupa penguasaan sejumlah materi pelajaran, siswa tidak sekedar mengetahui atau mengingat sejumlah konsep yang dipelajari, tetapi siswa mampu mengungkapan kembali dalam bentuk lain yang mudah dimengerti, dan mampu mengaplikasikan konsep yang sesuai dengan struktur kognitif yang dimilikinya. Sejalan dengan itu Kilpatrik (Lestari \& Yudhanegara, 2016) mengatakan bahwa kemampuan pemahaman konsep matematis siswa ialah kemampuan siswa yang berkenaan dengan memahami ide-ide matematika yang menyeluruh dan fungsional. Dari beberapa pendapat para ahli dapat disimpulkan bahwa kemampuan pemahaman konsep matematis siswa ialah kemampuan siswa mengungkapkan kembali suatu materi matematika yang disajikan dalam bentuk bahasa sendiri serta mampu mengaplikasikan apa yang telah dipelajari kedalam kegiatan belajar.

Menurut Kilpatrik (Lestari \& Yudhanegara, 2016) adapun indikator kemampuan pemahaman konsep matematis siswa yaitu:

1. Menyatakan ulang konsep yang telah dipelajari.

2. Mengklasifikasikan objek-objek berdasarkan konsep matematika

3. Menerapkan konsep secara algoritma

4. Memberikan contoh atau kontra contoh dari konsep yang dipelajari

5. Menyajikan konsep dalam berbagai representasi

6. Mengaitkan berbagai konsep matematika secara internal atau eksternal

Kemudian menurut Dahlan (Nuraeni \& Luritawaty, 2017)untuk indikator kemampuan pemahaman konsep matematis siswa ialah sebagai berikut: 

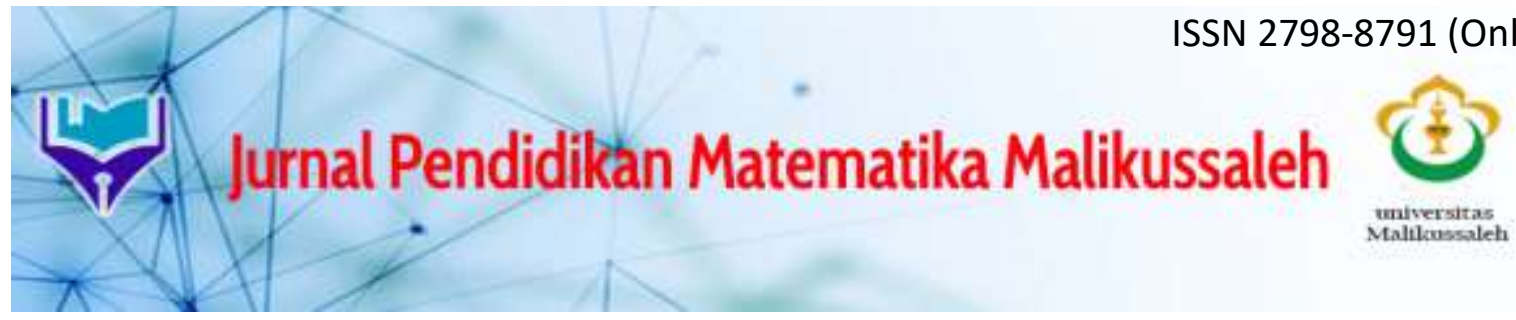

\section{Volume 1, Nomor 2, November 2021}

1 Kemampuan menyatakan ulang konsep yang telah dipelajari

2 Kemampuan mengklarifikasikan objek-objek berdasarkan dipenuhi atau tidaknya persyaratan yang membentuk konsep tersebut

3 Kemampuan mengembangkan syarat perlu dan atau syarat cukup suatu konsep

4 Kemampuan memberikan contoh dan counter example dari konsep yang telah dipelajari

5 Kemampuan menyajikan konsep dalam berbagai macam bentuk representasi matematika

6 Kemampuan mengkaitkan berbagai konsep (internal dan eksternal matematika)

7 Kemampuan menerapkan konsep secara algoritma

Berdasarkan pendapat beberapa para ahli di atas, maka dapat peneliti ambil kesimpulan bahwa indikator kemampuan pemahaman konsep matematis siswa yang dipakai pada penelitian ini adalah: (1) menyatakan ulang sebuah konsep, (2) memberi contoh dan bukan contoh dari suatu konsep, (3) mengklasifikasi objek menurut sifat-sifat tertentu sesuai dengan konsepnya, (4) mengaplikasikan konsep atau algoritma dalam pemecaham masalah (5) mengembangkan syarat perlu atau cukup dari suatu konsep.

(Sohimin, 2014) mengatakan bahwa model TGT adalah salah satu tipe model pembelajaran kooperatif yang mudah diterapkan, melibatkan aktivitas seluruh siswa tanpa harus ada perbedaan status, melibatkan peran siswa sebagai tutor sebaya, mengandung unsur permainan dan reinforcement. Teams Games Tournament (TGT) merupakan model pembelajaran kooperatif dimana menempatkan peserta didik pada kelompok belajar yang memiliki jenis kelamin, kemampuan, dan ras yang berbeda serta beranggotakan 5 sampai dengan 6 peserta didik (Fathurrohman, 2015).

Menurut (Fathurrohman, 2015), (Hariyanto, 2019), (Sohimin, 2014) langkah-langkah model pembelajaraan kooperatif tipe Teams Game Tournament (TGT) adalah sebagai berikut:

1. Penyajian Kelas (Class Precentation): Proses pembelajaran diawali oleh pendidik dengan menyampaikan materi dalam penyajian kelas atau sering juga disebut dengan presentasi kelas.

2. Belajar dalam Kelompok (Teams): Pendidik membagi kelas menjadi kelompok-kelompok berdasarkan kriteria kemampuan peserta didik, jenis kelamin, dan ras yang telah disiapkan sebelumya. Kelompok umumnya terdiri dari 4 sampai 5 orang peserta didik.

3. Permainan (Games): Games atau permainan terdiri dari pertanyaan-pertanyaan yang relevan dengan materi. Games terdiri dari kartu pertanyaan sederhana dan kartu jawaban yang telah disiapkan pendidik. Peserta didik memasangkan antara kartu soal dan kartu jawaban, peserta didik yang benar dalam memasangkan akan mendapat skor.

4. Pertandingan atau Lomba (Tournament): Tournament memainkan game terstruktur yang biasanya dilaksanakan setiap akhir materi pembelajaran yang sedang berlangsung. Pemilihan kelompok tournament yaitu siswa dipilih sesuai dengan kemampuan atau tingkat kecerdasan setiap siswa. Anak yang memiliki kemampuan tinggi dari setiap kelompok akan digabungkan dalam meja tournament 1, dan anak yang memiliki kemampuan sedang dari setiap kelompok akan digabungkan dalam meja tournament 2 dan 3, dan anak yang memiliki kemampuan rendah digabungkan dimeja tournament 4. Kegiatan tournament yang akan dilakukan ialah dengan menggunakan bantua media ludo yang telah dimodifikasi. 


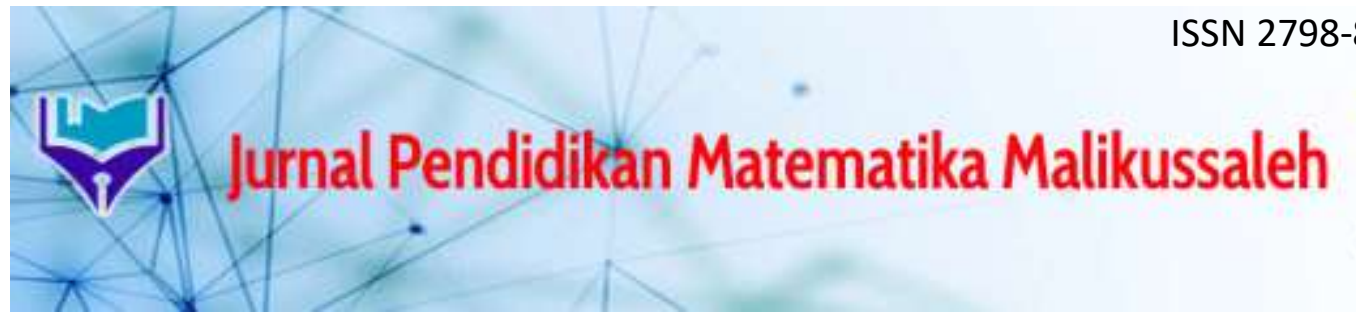

\section{Volume 1, Nomor 2, November 2021}

5. Penghargaan Kelompok (Team Recognition): Kegiatan kerja kelompok, games dan tournament apabila telah berakhir, pendidik kemudian mengumumkan kelompok yang menang, masing-masing kelompok akan mendapat hadiah apabila rata-rata skor memenuhi kriteria yang telah ditentukan.

Penggunaan model pembelajaran TGT dalam upaya memperbaiki kemampuan pemahaman konsep matematis siswa merupakan salah satu solusi dari permasalahan tersebut, namun dengan adanya bantuan alat peraga maka pembelajaran akan jauh lebih efektif dan dapat lebih tercapainya kemampuan siswa dalam memahami konsep matematis. Alat peraga peneliti gunakan adalah alat peraga Alperbus (Alat peraga balok kubus), kerangka kubus dan balok terbuat dari tusuk sate sedangkan untuk sisi-sisinya terbuat dari kertas karton warna warni. Cara penggunaan alat peraga ini ialah dengan membuka semua sisi sehingga terlihat jaring-jaring dari kubus dan balok, kemudian siswa dapat memahami konsep dari jaringjaring, dapat menemukan luas permukaan pada kubus dan balok setelah menghitung dan mengukur masing-masing pada sisi. Selanjutnya untuk volume kubus dan balok peneliti menambahkan kubus-kubus kecil yang terbuat dari kertas karton, ketika kubus-kubus kecilnya dimasukan pada kerangka kubus dan balok yang telah disiapkan siswa bersama dengan bimbingan guru dapat menemukan rumus dari volume kubus dan balok.

\section{METODE}

\section{Jenis Penelitian}

Penelitian ini menggunakan pendekatan penelitian kuantitatif karena data penelitian berupa angka-angka dan dianalisis menggunakan statistik, dan juga penelitian deskriptif karena dari data yang diperoleh akan menggambarkan proses penyelesaian jawaban siswa dengan jenis penelitian quasi experimental design (eksperimen semu). Pada penelitian ini menggunakan desain penelitian the nonequivalent posttest-only control grup design (Lestari \& Yudhanegara, 2015:136), rancangan desain terlihat seperti gambar 1 berikut ini.

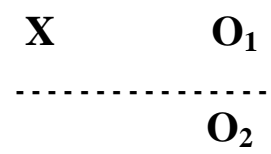
Keterangan:

Gambar 1 Rancangan the nonequivalent posttest-only control grup design

$\mathrm{X}$ : Perlakuan model TGT berbantuan alat peraga

$\mathrm{O}_{1}$ : Post-test kelas eksperimen

$\mathrm{O}_{2}$ : Post-test kelas kontrol

\section{Waktu dan Tempat Penelitian}

Penelitian ini dilaksanakan di MTsN 2 Aceh Tenggara Kec. Lawe Sigala-gala Kab. Aceh Tenggara. Adapun waktu penelitian ini berlangsung pada semester genap pada tahun ajaran 2020/2021.

\section{Populasi dan Sampel}

Populasi pada penelitian ini adalah seluruh siswa kelas VIII MTsN 2 Aceh Tenggara tahun ajaran 2020/2021 terdiri dari kelas VIIIA, VIIIB, dan VIIIC. Peneliti menggunakan 


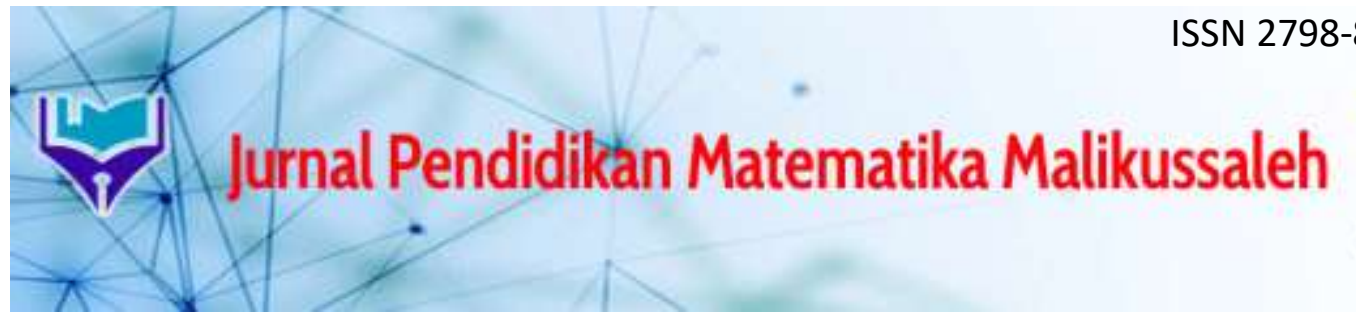

\section{Volume 1, Nomor 2, November 2021}

teknik purposive sampling yaitu teknik penentuan sampel dengan cara pertimbangan, adapun yang menjadi sampel dalam penelitian ini adalah siswa sebanyak dua kelas dari tiga kelas VIII. Sampel tersebut adalah kelas VIIIA sebagai kelas eksperimen dan kelas VIIIB sebagai kelas kontrol.

\section{Prosedur}

Tahap pelaksanaan dimulai dengan memberikan pembelajaran pada kedua kelas, kemudian memebrikan post test, selanjutnya pengolahan data post test. Pengolahan data dimulai dengan menguji persyaratan statistik yaitu uji normalitas data, uji homogenitas, dan kemudian melakukan uji hipotesis yaitu uji-t, terakhir membuat kesimpulan hasil penelitian. Seluruh pengujian statistik menggunakan bantuan program komputer SPSS 18 dan Microsoft office excel 2007.

\section{Data, Intrumen, dan Teknik Pengumpulan Data}

Adapun instrumen penelitian yang akan digunakan dalam penelitian ini adalah tes kemampuan pemahaman konsep matematis siswa yang terdiri dari 5 soal berbentuk uraian pada materi Bangun Ruang (kubus dan balok) sebagai soal post tes. Instrumen tes diujicobakan terlebih dahulu untuk melihat kelayakan berdasarkan tingkat validitas, reliabilitas, daya pembeda dan tingkat kesukaran pada setiap butir soal.

\section{Teknik Analisis Data}

Setelah keseluruhan data terkumpul, maka data diolah dengan menggunakan analisis statistik uji-t pada taraf signifikan $\alpha=0,05$. Langkah-langkah yang digunakan dalam pengolahan data ialah uji normalitas, ketika kedua data berdistribusi normal maka dilanjutkan uji homogenitas, dan didapat varinas kedua data homogeny maka melakukan uji hipotesis menggunakan Compare Independent-Samples t-test dengan bantuan Software SPSS 18. Adapun rumusan hipotesis nol $\left(\mathrm{H}_{0}\right)$ dan hipotesis alternatif $\left(\mathrm{H}_{1}\right)$ adalah sebagai berikut:

$\mathrm{H}_{0}: \mu_{1}=\mu_{2}$; Tidak terdapat pengaruh yang signifikan model pembelajaran Teams Games

Tournament (TGT) berbantuan alat peraga terhadap kemampuan pemahaman konsep matematis siswa pada materi bangun ruang sisi datar kelas VIII MTsN 2 Aceh Tenggara

$\mathrm{H}_{1}: \mu_{1} \neq \mu_{2}$; Terdapat pengaruh yang signifikan model pembelajaran Teams Games Tournament (TGT) berbantuan alat peraga terhadap kemampuan pemahaman konsep matematis siswa pada materi bangun ruang sisi datar kelas VIII MTsN 2 Aceh Tenggara

Kriteria pengambilan keputusan untuk pengujian data tersebut adalah sebagai berikut:

1. Jika nilai signifikan $<0,05$ maka $\mathrm{H}_{0}$ ditolak.

2. Jika nilai signifikan $\geq 0,05$ maka $\mathrm{H}_{0}$ diterima. 


\section{Jurnal Pendidikan Matematika Malikussaleh} *

\section{Volume 1, Nomor 2, November 2021}

\section{HASIL DAN PEMBAHASAN}

Berdasarkan hasil penelitian yang telah dilakukan maka didapat data post test menghasilkan data pada tabel 1 berikut:

Tabel 1 Data Skor Post Test Kemampuan Pemahaman Konsep Matematis Siswa

\begin{tabular}{|c|c|c|c|c|c|}
\hline Kelas & N & Minimum & Maximum & Mean & Std.Deviation \\
\hline Eksperimen & 25 & 8 & 18 & 13.56 & 3.267 \\
\hline Kontrol & 25 & 8 & 18 & 11.32 & 2.462 \\
\hline
\end{tabular}

Berdasarkan tabel 1 terlihat bahwa skor rata-rata kemampuan pemahaman konsep matematis siswa untuk kelas eksperimen yang telah diterapkan model pembelajaran TGT berbantuan alat peraga memperlihatkan hasil skor rata-rata nilai post test kelas eksperimen ialah sebesar 13.56 yang lebih baik dibandingkan skor rata-rata kelas kontrol sebesar 11.32 yang diterapkan pendekatan pembelajaran saintifik. Dari gambar diagram di atas dapat disimpulkan bahwa terdapat perbedaan skor rata-rata nilai post test pada kedua kelas setelah pembelajaran berlangsung.

Untuk mengetahui adanya pengaruh kemampuan pemahaman konsep matematis siswa yang diterapkan dengan model pembelajaran TGT berbantuan alat peraga pada materi bangun ruang sisi datar bagian kubus dan balok, maka dilakukan pengujian hipotesis dari hasil penelitian. Data yang digunakan ialah nilai post test kemampuan pemahaman konsep matematis siswa kelas eksperimen (VIII-B) dan kelas kontrol (VIII-A).

1. Uji Normalitas

Hasil uji normalitas dapat dilihat pada tabel 2 berikut:

Tabel 2 Uji Normalitas Skor Nilai Post Test

\begin{tabular}{|c|c|c|c|c|}
\hline \multirow{2}{*}{ Kelas } & \multicolumn{3}{|c|}{ Shapiro-wilk } & Kesimpulan \\
\cline { 2 - 5 } & Statistic & Df & Sig. & \\
\hline Eksperimen & .922 & 25 & .057 & $\mathrm{H}_{0}$ diterima \\
\hline Kontrol & .922 & 25 & .072 & $\mathrm{H}_{0}$ diterima \\
\hline
\end{tabular}

Berdasarkan tabel 4.7 dapat dilihat bahwa pada kelas eksperimen nilai Sig $=0.57>\alpha$ $=0.05$ sehingga $\mathrm{H}_{0}$ diterima dan pada kelas kontrol nilai Sig. $=0.072>\alpha=0.05$ sehingga $\mathrm{H}_{0}$ diterima. Maka dapat disimpulkan bahwa data post test kemampuan pemahaman konsep matematis siswa pada kelas eksperimen dan kelas kontrol berdistribusi normal.

2. Uji Homogenitas

Hasil uji homogenitas dapat dilihat pada tabel 3 berikut:

Tabel 3 Uji Homogenitas Skor Nilai Post Test

\begin{tabular}{|c|c|c|c|}
\hline \multicolumn{4}{|c|}{ Test of Homogeneity of Variances } \\
\hline Levene Statistic & $\mathrm{df} 1$ & $\mathrm{df} 2$ & Sig, \\
\hline 2.830 & 1 & 48 & .099 \\
\hline
\end{tabular}

Berdasarkan tabel 4.8 di atas, nilai uji homogenitasnya adalah Sig. 0.099 yang artinya nilai sig. $>0.05$,sehingga $\mathrm{H}_{0}$ diterima, maka dapat simpulkan bahwa data skor nilai post test varians kedua data homogen. Kemudian dapat dilanjutkan uji hipotesis. 

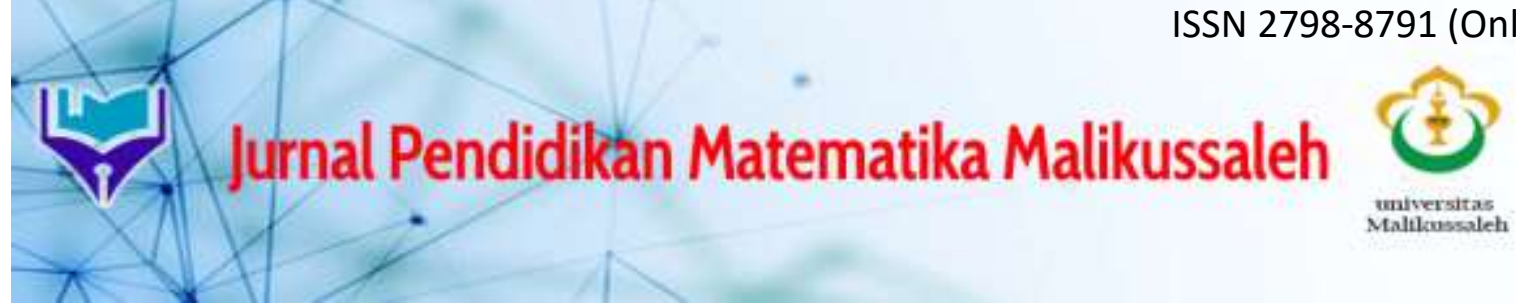

Volume 1, Nomor 2, November 2021

3. Uji Hipotesis

Pengujian hipotesis menggunakan Compare Independent-Samples t-test dengan bantuan software SPSS 18, taraf signifikan $0,05=\alpha$. Adapun hasilnya dapat dilihat pada tabel 4 berikut:

Tabel 4 Hasil Uji Hipotesis Data Post Test

\begin{tabular}{|c|c|c|c|c|}
\hline \multirow{3}{*}{ Post test } & & $\mathrm{T}$ & $\mathrm{Df}$ & Sig.(2-tailed) \\
\cline { 2 - 5 } & Equal Variances Assumed & 2.738 & 48 & .009 \\
\cline { 2 - 5 } & Equal Variances NotAssumed & 2.738 & 44.609 & .009 \\
\hline
\end{tabular}

Berdasarkan data pada tabel 4 menunjukan bahwa nilai sig. (2-tailed) adalah 0.009. Sehingga nilai sig. (2-tailed) $=0.009$ lebih kecil dari pada nilai taraf signifikan $\alpha=0,05$ maka diambil keputusan $\mathrm{H}_{0}$ ditolak atau $\mathrm{H}_{1}$ diterima. Dengan demikian dapat disimpulkan bahwa terdapat pengaruh yang signifikan model pembelajaran Teams Games Tournament (TGT) berbantuan alat peraga terhadap kemampuan pemahaman konsep matematis siswa pada materi bangun ruang sisi datar kelas VIII MTsN 2 Aceh Tenggara.

Penelitian pada pertemuan ke-1 peneliti memberikan perlakuan pada kelas eksperimen dengan menggunakan model pembelajaran TGT dan kelas kontrol menggunakan pendekatan pembelajaran saintifik dengan materi bagian-bagian dan luas permukaan kubus. Selanjutnya pertemuan ke-2 peneliti memberikan pengajaran mengenai materi bagian-bagian dan luas permukaan balok, kemudian pertemuan ke-3 peneliti membahas tentang materi volume kubus dan balok, dan pertemuan yang terakhir ke-4 peneliti memberikan post test kemampuan pemahaman konsep matematis kepada siswa. Pada pertemuan permata hingga pertemuan ketiga dalam proses pembelajaran peneliti menggunkan alat peraga Alperbus, gambar Alperbus dapat dilihat pada gambar 2 berikut.

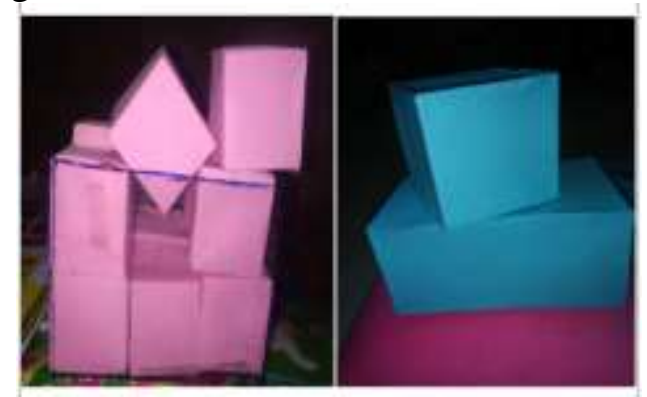

Gambar 2 Alat perga Alperbus

Soal post test yang diberikan bertujuan untuk melihat pengaruh model pembelajaran TGT berbantuan alat peraga terhadap kemampuan pemahaman konsep matematis siswa. Adapun soal yang diberikan sebanyak 5 butir soal yang berbentuk uraian yang sudah diuji sebelumnya, dimana setiap butir soal mewakili satu indikator kemampuan pemahaman konsep matematis siswa. Dari hasil post test yang telah dilakukan didapat bahwa model pembelajaran TGT berbantuan alat peraga berpengaruh secara signifikan terhadap kemampuan pemahaman konsep matematis siswa. Hal ini dapat dilihat dari hasil uji hipotesis menggunakan Compare Independent-Samples t-test dengan bantuan software SPSS 18.

Hasil uji yang didapat menggunakan software SPSS 18 yaitu sig. $(2$-tailed $)=0.009<$ $\alpha=0.05$ sehingga tolak $\mathrm{H}_{0}$ dan terima $\mathrm{H}_{1}$ yang artinya terdapat pengaruh yang signifikan model pembelajaran Teams Games Tournament (TGT) berbantuan alat peraga terhadap 


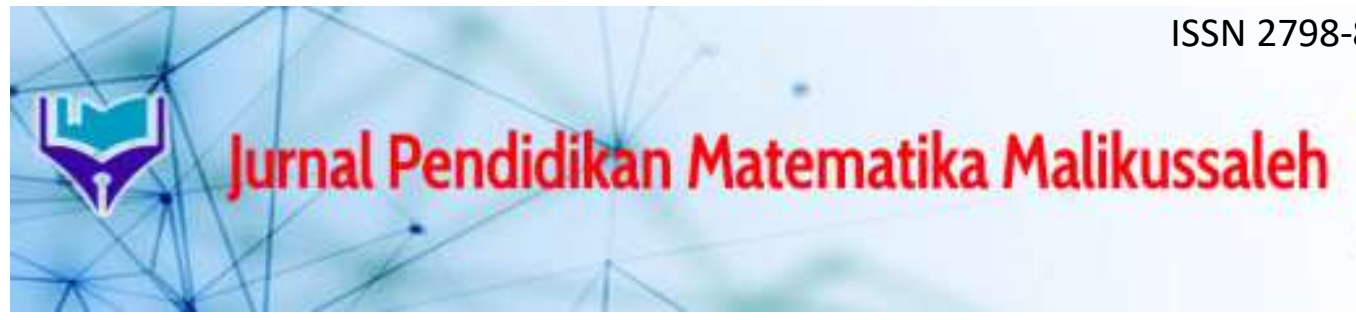

\section{Volume 1, Nomor 2, November 2021}

kemampuan pemahaman konsep matematis siswa pada materi bangun ruang sisi datar kelas VIII MTsN 2 Aceh Tenggara.

Selanjutkan berdasar analisis peneliti pada proses penyelesaian jawaban siswa setiap butir soal berdasarkan kemampuan pemahaman konsep matematis siswa di kelas eksperimen dan kelas kontrol terdapat perbedaan dalam menjawab soal dari kedua kelas, dimana siswa kelas eksperimen yang diberi perlakuan model pembelajaran TGT terlihat dalam menjawab soal lebih banyak siswa yang dapat memenuhi indikator kemampuan pemahaman konsep matematis siswa dari pada kelas kontrol dengan pendekatan pembelajaran saintifik. Siswa kelas eksperimen dalam mejawab soal tampak lebih berstruktur/beraturan dan tata bahasa yang mudah dipahami, dibandingkan siswa kelas kontrol dalam menjawab soal tampak kurang berstruktur/beraturan. Sejalan dengan hasil post test yang telah dianalisis datanya terdapat penagruh secara signifikan kemampuan pemahaman konsep matematis siswa yang belajar dengan model TGT.

\section{KESIMPULAN}

Berdasarkan hasil penelitian dapat disimpulkan bahwa terdapat pengaruh yang signifikan model pembelajaran Teams Games Tournament (TGT) berbantuan alat peraga terhadap kemampuan pemahaman konsep matematis siswa pada materi bangun ruang sisi datar kelas VIII MTsN 2 Aceh Tenggara, dan proses penyelesaian jawaban siswa pada kemampuan pemahaman konsep matematis siswa yang diberi perlakuan dengan menggunakan model pembelajaran Teams Games Tournament (TGT) lebih terarah dan terstruktur dalam menjawab soal dari pada jawaban siswa yang belajar menggunakan pendekatan pembelajaran saintifik kelas VIII MTsN 2 Aceh Tenggara.

\section{DAFTAR PUSTAKA}

Batubara, I. (2017). Peningkatan Kemampuan Pemahaman Konsep Matematis Melalui Model Pembelajaran Berbasis Masalah Berbantuan Autograph dan Geogebra di SMA Freemethodist Medan. MES (Journal of Mathematics Education and Science), $3(1): 47-54$.

Fathurrohman, M. (2015). Model-Model Pembelajaran Inovatif. Yogyakarta: Ar-Ruzz Media.

Hariyanto, F. (2019). Teams Games Tournament (TGT) \& Jigsaw Melalui Pendekatan Saintifik. Sleman: Deepublish.

Kemendikbud. (2014). Permendikbud No.58 tentang Kurikulum 2013 Sekolah Menengah Pertama/Madrasah Tsanawiyah. Jakarta: Kemendikbud.

Lestari, K., \& Yudhanegara, M. (2016). Penelitian Pendidikan Matematika. Bandung: PT Refika Aditama. 
Volume 1, Nomor 2, November 2021

Nuraeni, R., \& Luritawaty, I. (2017). Perbandingan Kemampuan pemahaman Matematis Siswa antara yang Menggunakan Pembelajaran Inside-Outside circle dengan Konvensional. Jurnal mosharafa, 6(3):441-450.

Rahmat, F., Suwatno, \& Rasto. (2018). Meningkatkan Pemahaman Konsep Siswa Melalui Teams games Tournament (TGT). Manajerial, 3(5):239-246.

Rohmah, E., \& Wahyudi. (2016). Pengaruh Model Pembelajaran Kooperatif Tipe Teams Games Tournament (TGT) Berbantuan Media Game Online Terhadap Pemahaman konsep dan Penalaran Matematis Siswa. Jurnal Pendidikan Dasar, 8(2):126-143.

Sohimin, A. (2014). Model Pembelajaran Inovatif dalam Kurikulum 2013. Yogyakarta: ArRuzz Media. 